\title{
DIAGNOSTICO EDAFOLOGICO PARA LA PLANIFICACION DE HUERTAS ORGANICAS FAMILIARES EN SUELOS PERIURBANOS
}

\author{
Giuffré, L. ${ }^{1}$; Marbán, L. ${ }^{1}$; Romaniuk, R. ${ }^{1}$; Vespasiano, C. ${ }^{1}$; Sammartino, \\ $F^{2} \&$ ARATA, L. ${ }^{2}$
}

\section{RESUMEN}

El objetivo del trabajo es plantear un diagnóstico edafológico previo a la planificación de huertas en suelos periurbanos de Escobar y Pilar (provincia de Buenos Aires), en el marco del Plan Huertas Fase 2 del proyecto de la ONG “Un Techo para mi país". Se realizaron análisis de rutina para evaluar las condiciones productivas, y análisis de metales pesados $\mathrm{Cd}, \mathrm{Cr}, \mathrm{Cu}, \mathrm{Ni}, \mathrm{Pb}$ y $\mathrm{Zn}$, dado que puede haber riesgos para la salud humana por su entrada en la cadena trófica. No se identificaron factores limitantes antrópicos en los barrios estudiados, las condiciones de fertilidad fueron apropiadas, y los valores de medios y máximos de los metales resultaron aceptables según lo estipulado en la legislación argentina.

Palabras clave: horticultura periurbana, diagnóstico edafológico, metales pesados.

\section{SUMMARY}

\section{Edaphological diagnosis for family organic orchards planning in periurban soils.}

The objective of this paper is to present a previous edaphological diagnosis for orchard planning in peri-urban soils of Pilar and Escobar (Buenos Aires province), in the framework of the Phase 2 Orchards Project of the NGO "A Roof for my country."

Routine analysis were performed to evaluate the productive conditions, and heavy metals $\mathrm{Cd}, \mathrm{Cr}$, $\mathrm{Cu}, \mathrm{Ni}, \mathrm{Pb}$ and $\mathrm{Zn}$ analysis, as there may be risks to human health for its entry into the food chain No anthropogenic limiting factors were identified in the neighborhoods studied, fertility conditions were appropriate, and average and maximum values of the metals were acceptable as stipulated in the argentine legislation.

Key words: periurban horticulture, edaphological diagnosis, heavy metals.

1.- Cátedra de Edafología FAUBA, Universidad de Buenos Aires. Av. San Martín 4453. CABA. Tel: 45248059. giuffre@agro.uba.ar

2.- Voluntarios de la ONG Un Techo para mi país.

Proyecto UBANEX 5 2013-2014. Plan de huertas periurbanas de la ONG "Un Techo Para Mi País"."Expansión Escobar 2013".

Manuscrito recibido el 5 de noviembre de 2013 y aceptado para su publicación el 26 de febrero de 2014. 